\title{
The Effectiveness of Advertising in Relation to the Personality of the Consumer
}

\author{
Zuzana BIRKNEROVÁ ${ }^{1, *}$, Radovan BAČÍI ${ }^{2}$, Jaroslava GBUROVÁ ${ }^{2}$ \\ ${ }^{1}$ Department of Managerial Psychology Faculty of Management, University of Prešov in Prešov, Prešov, Slovakia \\ ${ }^{2}$ Department of Marketing and International Trade Faculty of Management, University of Prešov in Prešov, Prešov, Slovakia \\ *Corresponding author: zuzana.birknerova@unipo.sk
}

Received January 19, 2013; Revised March 18, 2013; Accepted April 21, 2013

\begin{abstract}
Advertising creates a communication relationship between the producer or the provider of a service and the target group or the consumers. The main task of psychology of advertising is to motivate the consumer to take the desired action, to buy the promoted product or service. That is why more and more sophisticated forms and tools for reaching the goal set by the advertisment creator are used. The aim of the presented study was to determine whether an individual's temperament plays a major role in favouring a particular advertising spot and to identify which type of advertising corresponds with the type of a consumer's personality temperament. The research sample consisted of 126 respondents with different types of temperaments, aged between 22 to 68 years, who filled out two methodologies: Assessment of the television advertising in relation to personality typologies [1] and the EPI Eysenck Personality Inventory [2]. By means of this research, the existence of a relationship between temperament of individuals and their perception of various types of advertising spots (funny, calm, nostalgic, dynamic) was recorded. A successful advertisement should be aimed properly at a given group of individuals whom it should effectively reach. For that reason, psychology becomes an essential part in marketing and advertising strategies.
\end{abstract}

Keywords: advertising, temperament, consumer, personality, methodology

\section{Introduction}

Advertising is a way of informing the public about the producer's own activities, products, services for the purpose of establishment, or increasing the market needs and thereby increasing the profit of a company which uses this advertising [3]. It is a controlled communication process of a non-personal character which through mass media tries to introduce a specific object to the product and also affect its selling or acceptance [4]. The retailer, the producer of the product or service communicates with customers through a variety of media [5,6] define advertising as any form of a paid, non-personal presentation and promotion of products, services or ideas of a certain type, which uses press, television and radio broadcasting, external and other forms. According to [7] it is one-sided and does not provide information about the negative aspects.

A common indicator of all definitions is that advertising always creates a communication link between the producer or service provider and the target group, i.e. consumers. This communication takes place through a variety of media. According to [8] dismissals in mass communication are sold publicly, by technical means of communication, indirectly or to a unilaterally diffused audience. The opposite of mass communication is a direct advertisement which interferes particularly and personally to a defined audience. It is a good tool for marketing communication to inform and persuade people regardless of whether they support the product, service or idea [6]. It affects the customer through visualisation, sound, colors and printing more than any other tool of the communication mix [9].

The term advertising in connection to psychology is used as a psychological possibility of using the psychological knowledge within the whole communication process [10]. The role of psychology in advertising is to create an image that an individual inevitably needs the given product for personal use or social functioning. In accordance with [7], psychology of advertising uses more sophisticated forms and tools to achieve the goal set by the advertiser. Its task is to motivate the consumer to take the desired action and purchase the promoted product or service.

The addressee of an advertisement notification is the so-called recipient [11]. According to [10] it is every person in the role of a recipient of the notification, who has an already predetermined individual attitude, beliefs and criteria values that influence the advertising dealings. This includes all the elements of a complex personality structure which creates a dynamic system changing through the course of the time. In accordance with Eysenck (according to [12]) the personality is a comprehensive summary of current or potential patterns of the organism, which are determined by heredity and environment. They arise and develop through the interaction of cognitive (intelligence), conative (character), affective (temperament) and the somatic (constitution) area. 
For marketing purposes, creating the person-consumer types is mostly used on the basis of searching for the common factors. Psychological typology must take into account not only the personality of the consumer, but also the nature of the consumer product. Classification of a target group based on psychological criteria is, according to [10], not simple. Analyzing attitudes, motives and personality traits is difficult. In this research the attention is paid to the affective area using one of the oldest and most popular typologies by Hippocrates [13]:

- sanguine - lively, active, cheerful, optimistic, handles any crises, light-hearted, repetitive, talkative and not persistent;

- melancholic - more serious and sad, consumed by thoughts, indecisive, anxious, pessimistic, more complex, having fear of the outside world and a rich inner life, selfsacrificing, cultural and idealistic;

- choleric - hotheaded, active, bossy, easily angered, recognized but not very popular, adventurous, resourceful, confident, self-sufficient, strong and honest;

- phlegmatic - having slower reactions, calm and collected, convenient, slow worker but reliable, bad companion, peaceful, submissive, meek and boring.

The need to understand the behavior of a certain group of consumers in a particular moment, in a particular environment, and in relation to a particular product or service requires psychological analysis. Temperament is formed by an affective area, which contains strong, vigorously on-going, and variously long-lasting emotional outbursts.

\section{Research Materials and Methods}

Birknerová and Bačík [1] developed and verified a methodology for television advertising spots in relation to the temperament types of respondents. The research sample consisted of 10 experts in advertising, who were approached within the psychological and marketing communities. On the basis of watching the available advertising spots in the market, the selection of appropriate television commercials, which were used for further analysis, was carried out. The experts selected 4 specific television commercials based on the evaluation of representativeness of the selected advertisements in relation to the observed criteria. These were subsequently used to create a research methodology labeled "Assessment of the television advertising in relation to personality typologies". This methodology along with the personality questionnaire was filled out by 126 respondents, 72 of whom were women and 54 men with different types of temperaments and age between 22 and 68 years, the average age being 39.12 years.

\subsection{Research Methodology}

We used two methodologies to collect data. The first, created by the authors Birknerová and Bačík [1], is titled: Assessment of the television advertising in relation to personality typologies. To create a questionnaire of advertising temperaments, the authors used four most suitable images from the advertisements which describe a specific situation best. This they combined with the 32 substantives in a different order (temperaments, positive and negative features). The assessment was carried out on a scale from 1 to 6 , where 1 represents the evaluation "completely vague" and 6 means "completely accurate". In the introduction of their methodology, the authors put forward the following question: "How accurately do the individual words describe the given advertisement?" The next step presents the instruction for the respondent, a table with a range of assessments, the individual substantives, and the main part of the methodology consists of the image of a particular advertisement and the link to its source.

The second methodology used is the EPI - Eysenck Personality Inventory, which belongs to the set of most popular personality questionnaires. Since 1979, it has been re-standardized to be used for the Slovak population. The EPI methodology is used both for the basic and the applied research for clinical and consultancy purposes. It consists of 57 questions, 24 of which measure extraversion (E scale), 24 diagnose neurotic tendencies ( $N$ scale) and 9 create the scale of lie (L range). The persons under observation gives short "yes" and "no" answers to all questions [14].

\subsection{Research Goal}

The main objective of this research was to determine whether the recipient's temperament plays a major role in favouring the given advertising spot and if so, to identify which type of advertisement corresponds with the particular type of temperament.

\section{Results and Interpretation}

\subsection{Hypothesis 1 and Its Verification}

We predict significantly higher values of substantives for the sanguines in the humorous advertisements as compared to the values of substantives for the cholerics, melancholics and phlegmatics.

Table 1 (first column) records constituent values of the average order (AO) of substantives, which were recorded by respondents after the presentation of a humorous commercial. We used the non-parametric Kruskal-Wallis test for their verification. The test was used in all advertisements in four substantives, which we compared in terms of temperament groups. The signification indicates the statistical significance (Table 2). The average order indicates the direction of the differences (Table 1).

The results of the Kruskal-Wallis test show a statistically significant difference between the temperament groups in substantives in a sanguine advertisement: the substantives for the sanguines (Chi = 9.485, Sig $=0.040)$, phlegmatics $(\mathrm{Chi}=9.666$, $\mathrm{Sig}=$ $0.022)$ and the melancholics $(\mathrm{Chi}=11.369$, Sig. $=0.010)$. We can conclude that the assumption of significantly higher values of substantives for the sanguines in a sanguine advertisement as compared to other temperament groups was confirmed. The sanguines scored the highest in the substantives for this group $(\mathrm{AO}=30.95)$ in a humorous advertisment. The statistically significant differences between the temperament groups in the substantives of sanguine advertising are in the substantives for the sanguines, phlegmatics and melancholics. 
Table 1. Advertising and its evaluation according to the substantives: the average order (AO)

\begin{tabular}{|c|c|c|c|c|}
\hline Temperament & Sanguine advertising & Phlegmatic advertising & Melancholic advertising & $\begin{array}{c}\text { Choleric } \\
\text { advertising }\end{array}$ \\
\hline & $\begin{array}{l}\text { Substantives for the } \\
\text { sanguines (AO) }\end{array}$ & $\begin{array}{l}\text { Substantives for the } \\
\text { sanguines (AO) }\end{array}$ & $\begin{array}{l}\text { Substantives for the } \\
\text { sanguines (AO) }\end{array}$ & $\begin{array}{l}\text { Substantives for the } \\
\text { sanguines (AO) }\end{array}$ \\
\hline Sanguine & 30.95 & 19.10 & 23.35 & 11.05 \\
\hline Phlegmatic & 23.05 & 29.40 & 16.00 & 16.50 \\
\hline Melancholic & 17.50 & 15.35 & 22.45 & 24.30 \\
\hline \multirow[t]{2}{*}{ Choleric } & 15.30 & 18.15 & 12.20 & 30.15 \\
\hline & $\begin{array}{l}\text { Substantives for the } \\
\text { phlegmatics (AO) }\end{array}$ & $\begin{array}{l}\text { Substantives for the } \\
\text { phlegmatics (AO) }\end{array}$ & $\begin{array}{l}\text { Substantives for the } \\
\text { phlegmatics (AO) }\end{array}$ & $\begin{array}{l}\text { Substantives for the } \\
\text { phlegmatics (AO) }\end{array}$ \\
\hline Sanguine & 20.50 & 15.10 & 11.40 & 13.45 \\
\hline Phlegmatic & 29.75 & 29.80 & 14.25 & 28.15 \\
\hline Melancholic & 19.85 & 21.25 & 29.80 & 21.95 \\
\hline \multirow[t]{2}{*}{ Choleric } & 28.90 & 17.85 & 26.55 & 18.45 \\
\hline & $\begin{array}{l}\text { Substantives for the } \\
\text { melancholics (AO) }\end{array}$ & $\begin{array}{l}\text { Substantives for the } \\
\text { melancholics (AO) }\end{array}$ & $\begin{array}{l}\text { Substantives for the } \\
\text { melancholics (AO) }\end{array}$ & $\begin{array}{l}\text { Substantives for the } \\
\text { melancholics (AO) }\end{array}$ \\
\hline Sanguine & 18.15 & 13.10 & 26.45 & 21.20 \\
\hline Phlegmatic & 22.85 & 25.05 & 12.05 & 14.90 \\
\hline Melancholic & 28.95 & 19.20 & 29.95 & 16.75 \\
\hline \multirow[t]{2}{*}{ Choleric } & 12.05 & 24.65 & 19.55 & 29.15 \\
\hline & $\begin{array}{l}\text { Substantives for the } \\
\text { cholerics (AO) }\end{array}$ & $\begin{array}{l}\text { Substantives for the } \\
\text { cholerics (AO) }\end{array}$ & $\begin{array}{l}\text { Substantives for the } \\
\text { cholerics (AO) }\end{array}$ & $\begin{array}{l}\text { Substantives for the } \\
\text { cholerics (AO) }\end{array}$ \\
\hline Sanguine & 14.20 & 20.90 & 21.20 & 15.55 \\
\hline Phlegmatic & 26.75 & 27.85 & 14.90 & 15.75 \\
\hline Melancholic & 18.10 & 18.75 & 28.50 & 28.15 \\
\hline Choleric & 22.95 & 14.50 & 17.40 & 22.55 \\
\hline
\end{tabular}

Table 2. Kruskal-Wallis test of the sanguine advertisement

\begin{tabular}{|c|c|c|c|c|}
\hline \multicolumn{2}{|c|}{$\begin{array}{c}\text { Kruskal-Wallis test - } \\
\text { sanguine } \\
\text { advertisement }\end{array}$} & & & \\
\hline & $\begin{array}{c}\text { Substantive } \\
\text { for the } \\
\text { sanguines }\end{array}$ & $\begin{array}{c}\text { Substantive } \\
\text { for the } \\
\text { phlegmatics }\end{array}$ & $\begin{array}{c}\text { Substantive } \\
\text { for the } \\
\text { melancholics }\end{array}$ & $\begin{array}{l}\text { Substantive } \\
\text { for the } \\
\text { cholerics }\end{array}$ \\
\hline $\begin{array}{l}\text { Chi- } \\
\text { square }\end{array}$ & 9.485 & 9.666 & 11.369 & 6.670 \\
\hline Sig. & 0.040 & 0.022 & 0.010 & 0.083 \\
\hline
\end{tabular}

\subsection{Hypothesis 2 and Its Verification}

We assume significantly higher values of phlegmaticoriented substantives for the phlegmatics in a calm advertisement as compared to the phlegmatic-oriented substantive values for the sanguines, cholerics and melancholics.

Table 1 (second column) records the constituent values of the average order ( $\mathrm{AO})$ of substantives, which were recorded by the respondents after the presentation of the calm advertisement. For their verification we also used the non-parametric Kruskal-Wallis test. The test was used in all advertisements in four substantives, which we then compared in terms of temperament groups. The signification indicates the statistical significance (Table 3).

Table 3 illustrates the statistically significant differences between the temperament groups in substantives in a phlegmatic advertisement: in the substantive for the sanguines $(\mathrm{Chi}=8.350$, Sig. $=0.039)$ and for the phlegmatics $(\mathrm{Chi}=7.618, \mathrm{Sig}=0.005)$. No statistically significant differences were found in the rest of the substantives. We can conclude that the assumption of significantly higher values of substantives for the phlegmatics in their group for the calm advertisement as compared to the other temperament groups substantive values was confirmed. The phlegmatics scored the highest in the substantives $(\mathrm{AO}=29.80)$ within their group in the calm advertisement. Statistically significant differences between the temperament groups in the substantives in a phlegmatic advertisement are: in the substantive for the sanguines and the phlegmatics.

Table 3. Kruskal-Wallis test of the phlegmatic advertisement

\begin{tabular}{|c|c|c|c|c|}
\hline \multicolumn{2}{|c|}{$\begin{array}{c}\text { Kruskal-Wallis test - } \\
\text { phlegmatic } \\
\text { advertisement }\end{array}$} & \multirow[b]{2}{*}{$\begin{array}{l}\text { Substantive } \\
\text { for the } \\
\text { phlegmatics }\end{array}$} & \multirow[b]{2}{*}{$\begin{array}{c}\text { Substantive } \\
\text { for the } \\
\text { melancholics }\end{array}$} & \multirow[b]{2}{*}{$\begin{array}{c}\text { Substantive } \\
\text { for the } \\
\text { cholerics }\end{array}$} \\
\hline & $\begin{array}{c}\text { Substantive } \\
\text { for the } \\
\text { sanguines }\end{array}$ & & & \\
\hline $\begin{array}{l}\text { Chi- } \\
\text { square }\end{array}$ & 8.350 & 7.618 & 6.968 & 6.949 \\
\hline Sig. & 0.039 & 0.005 & 0.073 & 0.074 \\
\hline
\end{tabular}

\subsection{Hypothesis 3 and its Verification}

We predict significantly higher values of substantives for the melancholics within their group in a nostalgic advertising as compared to the melancholic values of substantives for the sanguines, phlegmatics and cholerics.

Table 1 (third column) records the constituent values of the average order (AO) of substantives, which were recorded by the respondents after the presentation of the nostalgic advertisement. Again we used the nonparametric Kruskal-Wallis test for their verification. The signification indicates the statistical significance (Table 4).

Table 4 shows statistically significant differences between the temperament groups in the substantives for the melancholic advertisement: in the substantive for the sanguines $(\mathrm{Chi}=15.565, \mathrm{Sig} .=0.001)$, for the phlegmatics $(\mathrm{Chi}=18.014$, Sig $=0.000)$, for the melancholics $(\mathrm{Chi}=8.832$, Sig. $=0.032)$ and for the first time, just above the borderline of significance, also for the 
cholerics $(\mathrm{Chi}=7.767$, Sig. $=0.050)$. We can conclude that the assumption of significantly higher values of substantives for the melancholics within their group for the nostalgic advertisement as compared to the other temperament groups' substantive values was confirmed. The melancholics scored the highest in the substantives $(\mathrm{AO}=29.95)$ within their group in the nostalgic advertisement. Statistically significant differences between the temperament groups in the substantives for the melancholic advertisement are in the substantive for all four temperaments.

Table 4. Kruskal-Wallis test of the melancholic advertisement

\begin{tabular}{|c|c|c|c|c|}
\hline $\begin{array}{c}\text { Kruskal-Wallis test - } \\
\text { melancholic } \\
\text { advertisement }\end{array}$ & $\begin{array}{c}\text { Substantive } \\
\text { for the } \\
\text { sanguines }\end{array}$ & $\begin{array}{c}\text { Substantive } \\
\text { for the } \\
\text { phlegmatics }\end{array}$ & $\begin{array}{c}\text { Substantive } \\
\text { for the } \\
\text { melancholics }\end{array}$ & $\begin{array}{c}\text { Substantive } \\
\text { for the } \\
\text { cholerics }\end{array}$ \\
\hline $\begin{array}{c}\text { Chi- } \\
\text { square }\end{array}$ & 15.565 & 18.014 & 8.832 & 7.767 \\
\hline Sig. & $\mathbf{0 . 0 0 1}$ & $\mathbf{0 . 0 0 0}$ & $\mathbf{0 . 0 3 2}$ & $\mathbf{0 . 0 5 0}$ \\
\hline
\end{tabular}

\subsection{Hypothesis 4 and Its Verification}

We predict significantly higher values of substantives for the cholerics within their group for a dynamic advertisement as compared to the choleric values of substantives for the sanguines, phlegmatics and melancholics.

Table 1 (fourth column) records the constituent values of the average order (AO) of substantives, which were recorded by the respondents after the presentation of a dynamic advertisement. The signification of the nonparametric Kruskal-Wallis test indicates the statistical significance illustrated in Table 5.

Table 5. Kruskal-Wallis test of the choleric advertisement

\begin{tabular}{|c|c|c|c|c|}
\hline \multicolumn{2}{|c|}{$\begin{array}{c}\text { Kruskal-Wallis test - } \\
\text { phlegmatic } \\
\text { advertisement }\end{array}$} & \multirow[b]{2}{*}{$\begin{array}{l}\text { Substantive } \\
\text { for the } \\
\text { phlegmatics }\end{array}$} & \multirow[b]{2}{*}{$\begin{array}{l}\text { Substantive } \\
\text { for the } \\
\text { melancholics }\end{array}$} & \multirow[b]{2}{*}{$\begin{array}{c}\text { Substantive } \\
\text { for the } \\
\text { cholerics }\end{array}$} \\
\hline & $\begin{array}{l}\text { Substantive } \\
\text { for the } \\
\text { sanguines }\end{array}$ & & & \\
\hline $\begin{array}{l}\text { Chi- } \\
\text { square }\end{array}$ & 15.649 & 8.478 & 8.905 & 8.106 \\
\hline Sig. & 0.001 & 0.037 & 0.031 & 0.044 \\
\hline
\end{tabular}

Table 5 shows the statistically significant differences between the temperament groups in the substantives in the choleric advertisement again in all four temperaments: in the substantive for the sanguines $(\mathrm{Chi}=15.649$, Sig. $=$ 0.001), for the phlegmatics $(\mathrm{Chi}=8.478$, Sig. $=0.037)$, for the melancholics $(\mathrm{Chi}=8.905$, Sig. $=0.031)$ and the cholerics $(\mathrm{Chi}=8.106$, Sig $=0.044)$. We can conclude that the assumption of significantly higher values of substantives for the cholerics within this group in the dynamic advertisement as compared to the other temperament groups' substantive values was confirmed. Although the difference in the substantives is statistically significant for the cholerics, in the dynamic advertisement it was the melancholics $(\mathrm{AO}=28.15)$, not the cholerics $(\mathrm{AO}=22.55)$ who scored the highest within the four temperament groups. Statistically significant differences between the temperament groups in the substantives in a melancholic advertisement are in the substantive for all four temperaments.

\section{Discussion and Conclusion}

The aim of our research was to determine whether temperament plays a major role in favouring a particular advertising spot, and if so, to identify which type of advertising corresponds with the type of temperament. We used the methods developed by experts (the area of advertising and marketing psychology), and a questionnaire was developed to evaluate the television advertising in relation to the personality typologies [1]. The temperament types of the respondents were detected by means of the Eysenck Personality Inventory (EPI; [2]). The data was statistically evaluated and processed using the SPSS statistical program.

Based on the research analysis we can conclude that there is a relationship between the temperament of individuals (psychological characteristics of personality) and their perception of different types of commercial spots (humorous, calm, nostalgic, dynamic). [10] also notes that for a successful advertisement it is important and essential to be acquainted with the personality of the recipient. It should be specifically targeted to the group which it plans to address effectively. Therefore, psychology becomes an increasingly important part of marketing and advertising strategies.

The effectiveness of advertising depends on several factors. The most important is the goal of advertising, a product as such, the capacity of the real and the potential market and advertising costs. Advertising is trying to appeal to the emotions and psyche and sell a product which the consumer may not actually need. Whether the initiative from advertising affects the consumers and motivates them to purchase the advertised goods or services is affected by all particular individual's personal characteristics (education, temperament, abilities, skills, interests, values, and other fixed or variable factors).

We plan to continue with similar studies in the future and extend them to other personal characteristics of respondents in relation to advertising. We believe that our research will contribute to the psychology of advertising.

\section{Acknowledgements}

This research was financed by project GAMA/11/5 Identification of consumer's profile in the selected region of Slovakia.

\section{References}

[1] Birknerová, Z., Bačík, R. (2012) Reklama v psychológii - overenie metodiky. In Marketing a marketingová komunikácia - prepojenie teórie a praxe. Prešov: Prešovská univerzita v Prešove, Fakulta manažmentu, pp. 44-48.

[2] Eysenck, H.J., Eysenck, S.B.G. (1968) EOD: Eysenckov osobnostný dotazník - testová príručka. Bratislava: Psychodiagnostické a didaktické testy n. p. 23 p.

[3] Prachár, J. (1992) Reklama. (1 ${ }^{\text {st }}$ ed.). Bratislava: Ekonomická univerzita, $293 \mathrm{p}$.

[4] Síkorová, J. (2009) Reklama v procese DPH. Poradca 9, 2009. [Online] Available:

http://www.poradca.sk/SubPages/OtvorDokument/Clanok.aspx?id clanok=98866 (March 1, 2012).

[5] Mediaknowall. (2011) What is Advertising? [Online] Available: http://www.mediaknowall.com/gcse/advertising/advertising.php (March 1, 2012). 
[6] Pelsmacker, P., Geuens, M., Bergh, J. (2003) Marketingová komunikace. Praha: Grada Publishing, $600 \mathrm{p}$.

[7] Hudec, P. (2009) Reklama a psychológia. [Online] Available: http://beo.sk/masmedia/1046-reklama-a-psychologia (March 1, 2012).

[8] Mühlbacher, H. (1993) Selektivní propagace. (1 ${ }^{\text {st }}$ ed.). Praha: Nakladatelská společnost BaBText.

[9] Kotler, P., Armstrong, G. (2004) Marketing. ( $1^{\text {st }}$ ed.). Praha: Grada Publishing, $855 \mathrm{~s}$.

[10] Vysekalová, J. (2009) Psychologie reklamy. (3 ${ }^{\text {rd }}$ ed.). Praha : Grada Publishing, a. s., 294 p.
[11] Mediapol. (2010) Reklama - fenomén dnešnej doby. [Online] Available:

http://www.rodina-peniaze.sk/zaujimavosti.209/reklama-fenomendnesnej-doby. 21379.html (March 1, 2012).

[12] Hall, C., Lindzey, G. (2002) Psychológia osobnosti. ( ${ }^{\text {rd }}$ ed.). Bratislava: Svornost', a.s., 510 p.

[13] Mikuláštik, M. (2007) Manažérska psychologie. (1 ${ }^{\text {st }}$ ed.). Praha: Grada Publishing, a. s., 384 p.

[14] Svoboda, M. (1999) Psychologická diagnostika dopelých. (1 ${ }^{\text {st }}$ ed.). Praha: Portál, s. r. o., p. 342. 